\title{
Once-a-day milking of multiparous Holstein cows throughout the entire lactation: milk yield and composition, and nutritional status
}

\author{
Bernard RÉMOND ${ }^{\mathrm{a} *}$, Dominique POMIÈs ${ }^{\mathrm{b}}$, Didier DUPONT $^{\mathrm{c}}$, \\ Yves CHILLIARD ${ }^{\mathrm{b}}$
}

\author{
a École Nationale d'Ingénieurs des Travaux Agricoles, Unité Élevage et Production des Ruminants \\ (soutenue par l'INRA), 63370 Lempdes, France \\ b INRA, Unité de Recherche sur les Herbivores, 63122 Saint-Genès-Champanelle, France \\ c INRA, Station de Recherche en Technologie Laitière, 39800 Poligny, France
}

(Received 14 October 2003; accepted 23 March 2004)

\begin{abstract}
Once-a-day milking of multiparous Holstein cows throughout the entire lactation: milk yield and composition, and nutritional status. Eighteen multiparous Holstein cows were distributed into two similar groups immediately after calving: the control group (M2) was milked twice a day throughout lactation whereas the other group (M1) was milked only once a day in the morning. During the indoor (winter) period, all animals received the same total mixed ration ad libitum. In the summer, they were turned to pasture at the same time. The seven cows of group M2 (2 cows were excluded) produced $7323 \mathrm{~kg}$ of milk on average in 305 days. The nine cows of group M1 produced $5114 \mathrm{~kg}$ of milk $(-30 \% ; P<0.01)$ over an entire lactation that lasted 12 days less than the twice daily milked cows. Fat and protein concentrations were higher by $3.5 \mathrm{~g} \cdot \mathrm{kg}^{-1}(P<0.01)$ and $2.1 \mathrm{~g} \cdot \mathrm{kg}^{-1}(P=0.06)$, respectively, in the M1 group. Mean lactose contents (entire lactation) did not differ between groups $(P>0.10)$. Mean somatic cell count $\left(\log _{10}=5.043\right.$ per $\mathrm{mL}$ and 4.946 per $\mathrm{mL}$ in groups M1 and M2, respectively) did not differ between the groups despite the sharp increase noted in group M1 during the last third of lactation. Casein and whey protein contents also were not significantly different between the groups. Plasmin and lipoprotein lipase activities were unchanged although the plasminogen-derived activity tended to be higher in the milk from group M1. The dry matter (feed) mean intake amount of the first 14 weeks of lactation did not differ between the two groups although it gradually became higher in the M2 group. Group M1 cows' liveweight and body condition gradually improved over those of group M2, with a difference as high as $56 \mathrm{~kg}(P<0.01)$ and 0.94 point on the body condition score $(P=0.02)$ on the 36th week of lactation. Eight of the nine M1 cows and four of the seven M2 cows were diagnosed as pregnant. The M1 cows did not show any specific sanitary disorder or abnormal behaviour throughout the lactation.
\end{abstract}

once-a-day milking / dairy cow / milk yield / milk composition / nutritional status

Résumé - La traite une fois par jour de vaches laitières multipares Prim'holstein pendant toute la lactation : production laitière et état nutritionnel. Dix-huit vaches Prim'Holstein multipares ont été réparties en deux lots semblables dès le vêlage : le lot témoin (2M) a été trait deux fois par

* Corresponding author: remond@enitac.fr 
jour durant toute la lactation, tandis que l'autre lot $(1 \mathrm{M})$ n'était trait que le matin. Au cours de la période de stabulation les animaux ont reçu, à volonté, la même ration complète. Pendant l'été, ils ont été conduits ensemble au pâturage. Les 7 vaches du lot $2 \mathrm{M}$ ( 2 vaches éliminées) ont produit en moyenne $7323 \mathrm{~kg}$ de lait en 305 jours. Les 9 vaches du lot $1 \mathrm{M}$ ont produit $5114 \mathrm{~kg}(-30 \% ; P<$ $0,01)$ au cours d'une lactation plus courte de 12 jours en moyenne. Les teneurs en matières grasses et en protéines ont été plus élevées de, respectivement, $3,5 \mathrm{~g} \cdot \mathrm{kg}^{-1}(P<0,01)$ et $2,1 \mathrm{~g} \cdot \mathrm{kg}^{-1}(P=0,06)$ dans le lot $1 \mathrm{M}$. Les teneurs moyennes (sur la lactation) du lait en lactose n'ont pas été différentes entre les 2 lots $(P>0,10)$. Il en est de même des concentrations des cellules somatiques $\left(\log _{10}=\right.$ 5,043 par $\mathrm{mL}$ et 4,946 par $\mathrm{mL}$ pour les lots $1 \mathrm{M}$ et $2 \mathrm{M}$ ), malgré la forte augmentation observée dans le lot $1 \mathrm{M}$ au cours du dernier tiers de la lactation. La concentration des caséines et des protéines solubles n'a pas été significativement différente entre les lots. Les activités de la plasmine et de la lipoprotéine lipase n'ont pas été modifiées, mais l'activité dérivée du plasminogène a eu tendance à être plus élevée dans le lait du lot $1 \mathrm{M}$. La quantité de matière sèche ingérée au cours des 14 premières semaines de lactation n'a pas été, en moyenne, différente entre les 2 lots, mais elle est progressivement devenue plus élevée dans le lot $2 \mathrm{M}$. Le poids vif des vaches du lot $1 \mathrm{M}$ et leur état corporel sont progressivement devenus plus élevés que ceux du lot $2 \mathrm{M}$, la différence atteignant $56 \mathrm{~kg}$ à la $36^{\mathrm{e}}$ semaine de lactation $(P<0,01)$ et 0,94 point de note d'état corporel $(P=0,02)$. Huit des neuf vaches du lot $1 \mathrm{M}$ et quatre des sept vaches du lot $2 \mathrm{M}$ ont été diagnostiquées fécondées. Les vaches du lot $1 \mathrm{M}$ n'ont présenté aucun trouble sanitaire particulier et aucun comportement anormal.

traite une fois par jour / vache laitière / production laitière / composition du lait / état nutritionnel

\section{INTRODUCTION}

Standard, twice-a-day milking constitutes the most constraining task imposed on dairy producers because it has to be carried out routinely at morning and evening intervals. Milk producers have been attempting to lighten that burden, since it constitutes a main obstacle to improving their quality of life. Two broad solutions may be envisaged: either milking automation/robotisation, as is currently functional [3], or rescheduling to one daily milking, as commonly done by New Zealand farmers during the latter weeks of lactation. This practise is particularly suited to the milk production system operated in New Zealand which involves clustering of calvings and drying off.

The first-ever study conducted on oncea-day milking (ODM) more than 40 years ago [11] was practically never followed up until the late 1980s, since it reduced milk yield considerably (40 to 50 percent according to the authors). This precluded its implementation in the production context that prevailed a few decades ago: small farms, income directly linked to cows' productivity and a lower priority given to the quality of life in those days. ODM trials were resumed in the late 1980s, essentially in New Zealand where dairy farmers encouraged it (see review by Davis et al. [16]), and are ongoing in a few European countries such as Great Britain, Ireland and France. Also, a very small number of dairy farmers have been experimenting ODM in their own herds and their reports in the technical press have raised great interest on the part of many milk producers.

According to the literature data, the range of milk yield reduction associated with ODM is very wide. It varies from $10-20 \%[37,39$, 41] to $50 \%$ [11], because of the wide variability of experimental conditions (trial duration, cows' production level, lactation stage...). In most cases, losses appear to be higher at the beginning of lactation than at the end [7,38], in primiparous than in multiparous cows $[11,43]$ and in breeds whose milk contains less dry matter than in those with higher DM contents [7]. The consequences of ODM increase in proportion with the duration of its application $[11,31]$. Also, milk losses tend to be more noticeable when feeding levels are high than when they are low [1, 32], which enhances the potential interest of this technique in restricted 
dietary situations. Milk fat and protein contents are generally increased by ODM, whereas lactose content is reduced [16]. The effect of ODM on somatic cell count (SCC) is controversial. SCC is generally increased $[1,12,18,29]$, but not always [25, $33]$, possibly depending on the initial sanitary condition of the udder $[12,21]$. The mechanisms that lead to milk yield reduction and milk compositional changes have also been investigated. Alveolar milk accumulation seems to be the triggering factor of a spate of physiological changes leading to milk yield reduction [16]. Inter-individual differences in milk loss, as frequently reported $[6,11,18,23]$, residual milk amounts [6, 7], udder storage capacity [23] or the kinetics of milk storage [15] have been mentioned as influencing factors.

However, most of these results were obtained during relatively short-term trials (a few days to a few weeks) and at the end of lactation, with grazing animals that were relatively low producers, i.e. under conditions very different to those that prevail in France. This trial was an attempt to assess the main modifications induced by ODM throughout lactation on milk yield and composition.

\section{MATERIALS AND METHODS}

\subsection{Cows, husbandry and experimental protocol}

Eighteen multiparous Holstein cows (mean lactation rank $=2.9)$ were used. Immediately after calving (which occurred between 04/12/2000 and 02/02/2001; mean = $01 / 01 / 2001$ ), the cows were divided into two groups according to their lactation rank, liveweight, body condition score (as measured on 16 November 2000) and milk yield and composition (fat, protein and SCC), as recorded in weeks 4 to 16 of the previous lactation. One group was milked once a day from calving throughout lactation (group
M1) and the other group was milked twice daily (group M2).

Both groups were identically managed and fed throughout the trial duration. The cows, which were at pasture for the summer period before the experimental lactation, were returned to free stabling cubicles no later than the 1st of November 2000. They were given a complete ration composed (on a dry matter basis) of $72 \%$ maize silage, $8 \%$ hay, $15 \%$ soyabean cake, and $5 \%$ concentrate, balanced for milk production, ad libitum, in individual troughs fitted with electronically controlled gates. This ration was calculated with the Inration software [20] based on the 1989 Inra feeding allowances [19]. Cows were turned to pasture on 2 May. During the grazing period, all the cows were given $2 \mathrm{~kg} \cdot \mathrm{day}^{-1}$ concentrate from 14/05/01 to $29 / 07 / 01$, and from $17 / 09 / 01$ to $11 / 11 / 01$.

The cows were dried-off six weeks before their expected next calving date or whenever each of the two-week-average milk yields decreased to less than $6 \mathrm{~kg} \cdot \mathrm{day}^{-1}$. They were inseminated from the 40th lactation day when observed to be in oestrus.

M2 cows were milked at 6.30 a.m. and 5 p.m. M1 cows were milked at 6.30 a.m. Milking was done in a $2 \times 6$ station milking parlour (Europarallèle, Alpha Laval) fitted with automatic cluster removers and milk meters (Alpro). When the cows were at pasture, they were all led twice daily to stables adjacent to the milking parlour. During both the stabling and the grazing periods, those cows that were to be milked in the evening (M2 group) were segregated a few minutes before milking.

\subsection{Measurements}

Milk yield was measured at each milking. Milk samples were taken from Tuesdays' and Wednesdays' milkings for protein, fat and lactose assays by infrared spectrophotometry (Foss Electric, Hillerod, Denmark) and for somatic cell count (Fossmatic 5000 automatic counter, Foss Electric, Hillerod, Denmark). During lactation 
weeks 10 and 28 (on average), milk samples were taken on a single day, at each milking, for specific dosages: total nitrogen, nonprotein nitrogen and non-casein nitrogen were measured according to Rowland [34]; G1 immunoglobulins were assayed by radial immunodiffusion [27] and lipoprotein lipase (LPL) activity was measured using a radioactive substrate [17]; plasmin and plasminogen-derived activity were determined according to Bugaud et al.'s technique [4] and total calcium and phosphorus were determined by spectrometry. Residual milk amount following the morning milking was measured during lactation weeks 13 and 14 (two measurements per cow). Intramuscular injection of 50 UI oxytocin-S (Intervet) was performed immediately after the morning milking, in the milking parlour. The cluster was fitted four minutes after the injection, once the automatic removal device had been inactivated. All four udder quarters were manipulated in the course of milking to extract the maximum amount of milk. The clusters were removed manually whenever the milk flow from the udder was visually assessed as negligible. That measurement was repeated during the following week. Individual milk flow rates of 16 morning milkings were recorded between $05 / 03$ and $21 / 03$, i.e. in lactation week 10 on average.

Feed intake was measured on four days weekly during the stabling period. The cows were weighed between 1 p.m. and 2 p.m., twice during the first week after calving, then once every other week. Their body condition was assessed and rated 0 (very lean) to 5 (very fat) at calving, then monthly, according to Bazin [2].

Oestrus and insemination dates were recorded and pregnancy diagnosis was based on echographical examination. Health disorders were recorded.

\subsection{Statistical analyses}

Data statistical analysis was performed with the Proc GLM software [35], either by variance-covariance analysis (the covariates being the grouping parameters: milk, fat and protein contents, SCC during the previous lactation; liveweight and body condition score, as measured during the first week of the experimental lactation) or, in the absence of a covariate, by simple variance analysis (lactose...). Milk composition results from the two series of samples collected at mid-lactation and the results from residual milk measurements were subjected to repeated-datum analysis of variance (SAS). SCC was analysed on the basis of logarithmically transformed data.

Two M2 cows exhibited high SCC at the commencement of the experiment (782 000 per $\mathrm{mL}$ and 1903000 per $\mathrm{mL}$ during weeks 2 to 10 , on average), markedly higher than those of other cows $(18000$ per $\mathrm{mL}$ to 150000 per $\mathrm{mL}, 37000$ per $\mathrm{mL}$ on average), reflecting udder subpathological condition in these two cows. In consideration of the importance of rigorous assessment of the impact of ODM on milk yield, and SCC in particular, the data of those two cows were excluded from the calculation of the results.

\section{RESULTS}

According to (unscheduled) observations reported by cow handlers, the M1 cows did not appear to be bothered by being milked only once a day. In particular, their segregation from the M2 cows before the latter's evening milking did not raise any difficulty and they did not try to go towards the milking parlour.

\subsection{Milk yield}

The milk yield curve of the M1 group revealed a production peak of $8 \mathrm{~kg} \cdot$ day $^{-1}$ lower than the M2 group $(P<0.01 ;$ Fig. 1$)$, which occurred almost within the same time after calving for both groups (week 4.6 for M1 group vs. 5.6 for M2 group; $P>0.10$ ) and a lactation shorter by 12 days than the 


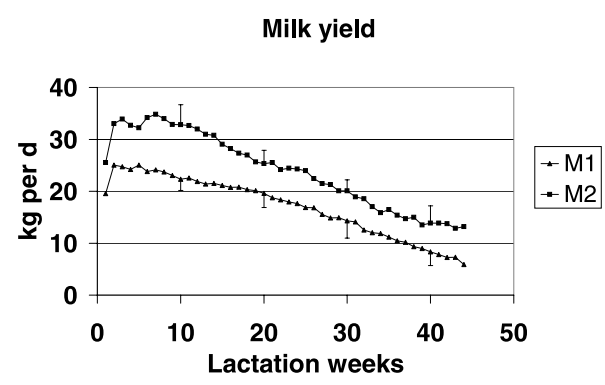

Figure 1. Evolution of milk yield (weekly mean, and standard deviation every ten weeks) during the first 44 lactation weeks in the groups of cows milked once-a-day (M1) or twice-aday (M2).

305-day duration of reference. All M2 cows were dried off after the 305th day of lactation whereas four M1 cows were dried off earlier (on the 285th day on average). Nonetheless, the weekly persistence computed after the lactation peak was identical in both groups $(98.1 \%$ and $98.2 \%$ in groups M1 and M2, respectively), making the lactation curves almost homothetical. The M1 cows produced $30.2 \%$ less milk than the M2 cows, on average, in 305 days (Tab. I). Milk flow rates at the morning milking were not significantly different between the two groups $\left(4.05 \mathrm{~kg} \cdot \mathrm{min}^{-1} \mathrm{vs} .3 .96 \mathrm{~kg} \cdot \mathrm{min}^{-1}\right.$ in $\mathrm{M} 1$ and $\mathrm{M} 2$ groups, respectively; $P>0.10$ ). The amount of residual milk at the morning milking was $38 \%$ lower in M1 cows than in
M2 cows $(1.5 \mathrm{~kg}$ vs. $2.4 \mathrm{~kg} ; P<0.05)$ although the former produced more milk (21.3 kg vs. $17.4 \mathrm{~kg}$, respectively). The proportion of residual milk in relation to the total milking volume was about twice as low in the M1 group than in the M2 group (7\% vs. $13 \%, P<0.01)$.

\subsection{Milk composition}

Fat and protein contents (balanced means for the whole lactation) were significantly higher in the M1 group and regularly so throughout the lactation, by $3.5 \mathrm{~g} \cdot \mathrm{kg}^{-1}$ and $2.1 \mathrm{~g} \cdot \mathrm{kg}^{-1}$, respectively (Tab. I and Fig. 2). Those higher contents only partially made up for the lower milk yield, so that the fat matter and protein amounts secreted by the M1 cows were $25 \%$ and $26 \%$ lower, respectively than those of the M2 cows. Mean lactose contents and SCC over the entire lactation did not significantly differ between the two groups. However, the lactose content difference gradually increased but never became significant $(P$ within 0.10 and 0.18 , for lactation weeks 30-40, with a mean lactose content difference of $2.7 \mathrm{~g} \cdot \mathrm{kg}^{-1}$ ). Somatic cell count increased rapidly in M1 cows from lactation week 30 . It was significantly higher in M1 $(0.05<P<0.10)$ compared to M2 milk during 7 of the last 15 lactation weeks.

The arithmetically higher true protein $\left(+1.9 \mathrm{~g} \cdot \mathrm{L}^{-1}\right)$, casein $\left(+1.2 \mathrm{~g} \cdot \mathrm{L}^{-1}\right)$ and whey

Table I. Milk yield and composition of cows milked once-a-day (M1) or twice-a-day (M2).

\begin{tabular}{|c|c|c|c|c|}
\hline & \multicolumn{2}{|c|}{ Group of cows } & \multirow[b]{2}{*}{ RSD } & \multirow{2}{*}{$\begin{array}{l}\text { Treatment } \\
\text { effect }(P)\end{array}$} \\
\hline & M1 & M2 & & \\
\hline Duration of lactation (d) & 293 & 305 & & \\
\hline Milk (kg in $305 \mathrm{~d})$ & 5114 & 7323 & 674 & $<0.01$ \\
\hline Fat $(\mathrm{kg}$ in $305 \mathrm{~d})$ & 236 & 315 & 27 & $<0.01$ \\
\hline Proteins (true) ( $\mathrm{kg}$ in $305 \mathrm{~d})$ & 167 & 225 & 21 & $<0.01$ \\
\hline Fat content $\left(\mathrm{g} \cdot \mathrm{kg}^{-1}\right)$ & 47.5 & 44.0 & 2.4 & 0.01 \\
\hline Protein (true) content $\left(\mathrm{g} \cdot \mathrm{kg}^{-1}\right)$ & 33.5 & 31.4 & 2.1 & 0.062 \\
\hline Lactose content $\left(\mathrm{g} \cdot \mathrm{kg}^{-1}\right)$ & 45.8 & 46.7 & 1.8 & 0.331 \\
\hline Somatic cell count $\left(\log _{10} \cdot \mathrm{mL}^{-1}\right)$ & 5.043 & 4.946 & 0.255 & 0.461 \\
\hline
\end{tabular}

RSD: residual standard deviation. 
(a) Fat

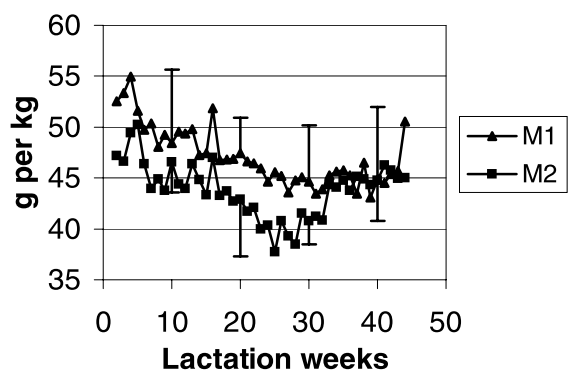

(b) Protein

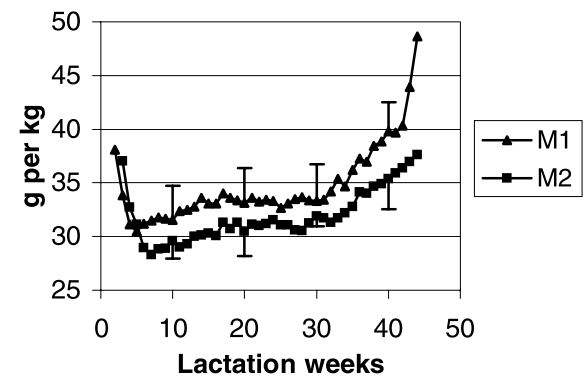

(c) Lactose

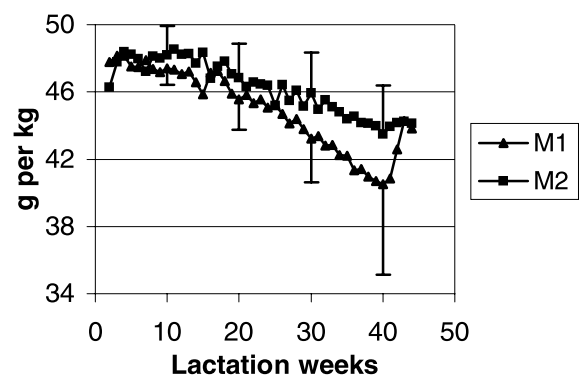

(d) Somatic cell count (geometric mean)

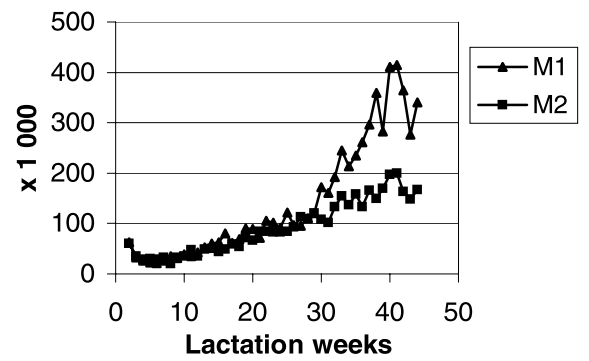

Figure 2. Evolution (weekly mean, and standard deviation every ten weeks) of the fat (a), protein (b), and lactose (c) contents and somatic cell count (geometric mean; d) throughout lactation in the groups of cows milked once-a-day (M1) or twice-a-day (M2).

Table II. Protein, calcium and phosphorus contents of milk from cows milked once-a-day (M1) or twice-a-day (M2).

\begin{tabular}{|c|c|c|c|c|c|}
\hline & \multicolumn{2}{|c|}{ Group of cows } & \multirow[b]{2}{*}{ RSD } & \multirow{2}{*}{$\begin{array}{c}\text { Period } \\
\text { effect }(P)\end{array}$} & \multirow{2}{*}{$\begin{array}{l}\text { Treatment } \\
\text { effect }(P)\end{array}$} \\
\hline & M1 & M2 & & & \\
\hline Proteins (true) $\left(\mathrm{g} \cdot \mathrm{kg}^{-1}\right)$ & 33.0 & 31.1 & 3.6 & $<0.01$ & 0.17 \\
\hline Caseins $\left(\mathrm{g} \cdot \mathrm{kg}^{-1}\right)$ & 26.7 & 25.5 & 3.2 & $<0.01$ & 0.30 \\
\hline Whey proteins $\left(\mathrm{g} \cdot \mathrm{kg}^{-1}\right)$ & 6.2 & 5.6 & 1.2 & 0.05 & 0.14 \\
\hline Caseins/proteins & 0.81 & 0.82 & 0.03 & 0.75 & 0.37 \\
\hline IgG1 $\left(\mathrm{g} \cdot \mathrm{kg}^{-1}\right)$ & 0.48 & 0.46 & 0.18 & 0.20 & 0.73 \\
\hline Calcium (total) $\left(\mathrm{g} \cdot \mathrm{kg}^{-1}\right)$ & 1.24 & 1.23 & 0.11 & $<0.01$ & 0.82 \\
\hline Phosphorus (total) $\left(\mathrm{g} \cdot \mathrm{kg}^{-1}\right)$ & 0.93 & 0.91 & 0.11 & $<0.01$ & 0.65 \\
\hline
\end{tabular}

RSD: residual standard deviation.

Analyses of milk samples taken in lactation weeks 10 and 28 (see Materials and Methods) according to the repeated measurement model.

The interaction group $\times$ week of sampling was not consistent for any of the constituents.

protein $\left(+0.6 \mathrm{~g} \cdot \mathrm{L}^{-1}\right)$ contents measured in the M1 milk samples collected in lactation weeks 10 and 28 were not significantly dif- ferent from those of the M2 samples (Tab. II). The increase in milk proteins noted in the M1 samples was largely due to 
Table III. Protease and lipase activities in the milk of cows milked once-a-day (M1) or twice-a-day (M2).

\begin{tabular}{|c|c|c|c|c|c|}
\hline & \multirow[b]{2}{*}{ Week } & \multicolumn{2}{|c|}{ Group of cows } & \multirow[b]{2}{*}{ RSD } & \multirow{2}{*}{$\begin{array}{c}\text { Treatment } \\
\text { effect }\end{array}$} \\
\hline & & M1 & M2 & & \\
\hline Plasmin (1) & 10 & 4.9 & 4.3 & 1.4 & 0.98 \\
\hline$\left(\mathrm{dA}_{405} \cdot \mathrm{dt}^{-1} \times 10^{4}\right)$ & 28 & 6.4 & 7.0 & & \\
\hline \multirow{4}{*}{$\begin{array}{l}\text { Plasminogen (2) } \\
\left(\mathrm{dA}_{405} \cdot \mathrm{dt}^{-1} \times 10^{4}\right) \\
(1) /(2)\end{array}$} & 10 & 34.4 & 30.2 & 7.3 & 0.27 \\
\hline & 28 & 45.4 & 34.6 & 6.7 & $<0.01$ \\
\hline & 10 & 0.17 & 0.15 & 0.05 & 0.61 \\
\hline & 28 & 0.15 & 0.21 & & \\
\hline \multirow{2}{*}{$\begin{array}{l}\text { Lipoprotein-lipase } \\
\left(\mathrm{nmol} \cdot \mathrm{mn}^{-1} \cdot \mathrm{mL}^{-1}\right)\end{array}$} & 10 & 449 & 525 & 142 & 0.21 \\
\hline & 28 & 439 & 623 & & \\
\hline
\end{tabular}

RSD: residual standard deviation.

Milk samples: see Table II. Statistical analyses according to the repeated measurement model when the group $\times$ week of sampling interaction was not significant. Otherwise, variance analysis per week.

caseins $(66 \%)$. The casein/protein ratio was not significantly affected. IgG, calcium and phosphorus concentrations did not differ between the two groups (Tab. II).

Plasmin activity was similar in both cow groups but that derived from plasminogen was significantly higher in M1 milk at the second sampling (Tab. III). Lipoprotein lipase activity did not differ significantly between the two groups.

\subsection{Nutritional indices, reproduction and pathology}

Daily feed intake amounts (dry matter), as computed with week 1 bodyweight as a covariate, were identical during lactation weeks 2 to 6 (means $19.3 \mathrm{~kg}$ and $19.5 \mathrm{~kg}$ in $\mathrm{M} 1$ and $\mathrm{M} 2$ groups, respectively; $P=0.88$ ). They were higher in the M2 group from week 7 (by $1.3 \mathrm{~kg}$ in weeks 7 to $14 ; P=0.14$ ) and the difference reached $2 \mathrm{~kg}(P=0.09)$ in week 14. M1 cows' liveweight decreased less and for a shorter period at the beginning of lactation than that of M2 cows (Fig. 3). Adjusted liveweight differences between the two groups gradually increased in the course of lactation, from $16 \mathrm{~kg}$ in week 5 $(P=0.31)$ to $56 \mathrm{~kg}$ in week $36(P<0.01)$. Body condition scores evolved in parallel with liveweight (Fig. 3). Score differences

\section{(a) Liveweight}

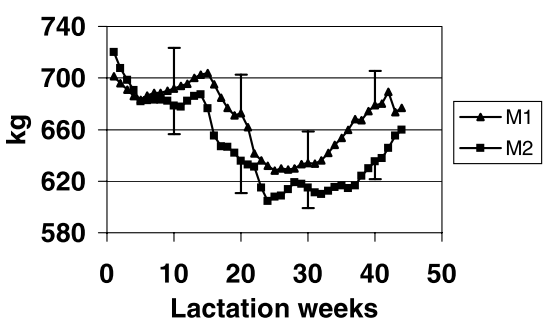

(b) Body condition score

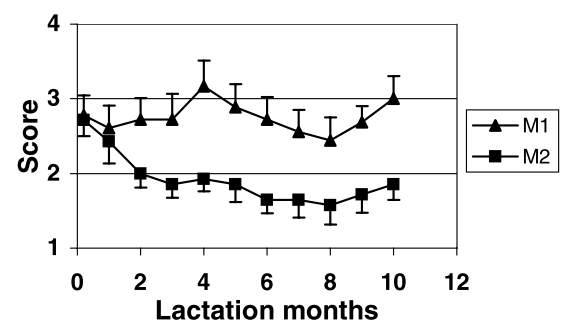

Figure 3. Evolution (mean and standard error) of the liveweight (a) and body condition score (b) throughout lactation in the groups of cows milked once-a-day (M1) or twice-a-day (M2).

between the two groups went from 0.28 points in week $5(P=0.22)$ to 0.94 points $(P=0.02)$ in week 36 . 
Eight of the nine M1 cows were diagnosed as pregnant 102 days on average after calving, whereas only four of the seven M2 cows were diagnosed as pregnant, three of which calved again and one had to undergo termination.

Considering the entire lactation, four cows in each group presented with limb disorders (lameness, footrot) and two mastitis cases (one in each group) were detected and managed.

\section{DISCUSSION}

This trial differed from most other published reports on three points: (1) it involved the entire lactation, (2) it was carried out with high producing and sustainably wellfed cows and (3) the udders of the experimental cows were all in good healthy condition at the beginning of the trial.

\subsection{Milk yield}

The results of the current study confirmed earlier reports: ODM was accompanied by a slight shortening of lactation (already noted by Claesson et al. [11] and similar to that described by Cooper [12], i.e., 14 days) and by a $30 \%$ decrease in milk yield, close to that recorded by Holmes et al. [18] and by Cooper [12] (35\% and 31\%, respectively) throughout entire lactations. The $50 \%$ and $40 \%$ milk yield reductions reported by Claesson [11] in primiparous and multiparous cows, respectively, may have been due to the use of lower producing cows which, in addition, were less selected for milking than they are now, both characteristics being likely to reinforce the negative impact of ODM on milk secretion [33]. The similarity of the milk rate decline throughout lactation in both groups may come as a surprise for 2 reasons: 1 / it is contrary to the observations of Claesson et al. [11] (increasing difference between the yields of milk by once and twice daily milked cows up to mid-lactation) and
Carruthers et al. [7] (nevertheless, Cooper [12] observed a similar rate of decline of the secretion of milk solids by once and twice daily milked cows); 2 / it seems hardly compatible with the increased rate of cellular death of udder alveoli (hypothesised by Davis et al. [16] as a consequence of ODM) that should induce a higher rate of decline of milk secretion [42]. Nevertheless those authors [42], in their modelling approach, also showed that the shape of the curve of lactation could be largely influenced by the level of nutrition of the cows, and Stelwagen [36] expressed that the relationship between milking frequency and lactational persistency is not apparent. In the current trial, the nutrient supply was more in excess over needs in the M1 group than in the M2 group, as shown by the evolution of liveweight and body condition score in both groups. That could have limited the potential detrimental effect of ODM on the persistency of lactation. The lower amount of residual milk (as $\mathrm{kg}$ or \%) recorded in this study in M1 cows confirmed the tendency observed by Carruthers et al. [8] (1.1 kg and $8.1 \%$ in cows milked once daily versus $1.4 \mathrm{~kg}$ and $12.8 \%$ in cows milked twice daily) which was ascribed to a low effectiveness of oxytocin (5 UI IV injection after normal milking) secondary to reduced blood irrigation following 24-h milk accumulation in the udder. In this trial, the higher oxytocin level (50 UI IM injection) and the 4-minute lag phase between injection and the beginning of the second milking did not alter the results. It may therefore be that ODM would induce a reduction of residual milk via a mechanism yet to be defined. This result could also contribute to explain the normal persistency of milk yield in the M1 group, since a high level of residual milk has been shown to be associated with a high milk loss on ODM [7].

\subsection{Milk composition}

The milk composition changes induced by ODM in this trial were consistent with earlier reports [16, 31-33]. The lack of 
statistical significance of the difference in lactose content between groups was surprising because a decrease in milk lactose content is classically the most consistent change induced by ODM [16]. Introducing the lactose contents recorded in early lactation (when they were similar for both groups) as a covariate in the mathematical model of analysis of the lactose contents recorded in late lactation (when they were increasingly different) did not make that difference more significant. The (non-significantly) higher casein and soluble protein contents of M1 cows' milk noted in this trial, by comparison with M2 cows' milk, were consistent with previously reported results $[11,26,29]$. They probably were caused by a better fulfilment of the cows' energy requirements [13] that did not modify the casein/protein ratio [14], and also by increased permeability of the mammary epithelium tight junctions [39], at least with whey proteins. However, the absence of modifications in SCC, IgG concentration, plasmin and lipoprotein lipase activity and the limited increase in plasminogenderived activity and lower lactose concentration indicate that the increase in tight junction permeability must have been restricted. As suggested earlier [32], implementing ODM at calving may have trained the udder to gradually adapt to the lower milking frequency, and hence limited the milk composition changes described as marked in the literature, after a sudden switch from two to one-only milking per day in the course of lactation.

The very low SCC of both milk groups during the first 30 weeks of lactation suggests that ODM did not affect that parameter during that period. Although most authors, working in conditions different from ours (trial duration...) observed increased SCC [18, 22, 28], other authors did not note any significant effect of ODM, especially in cows whose udders were free of bacteria or whose milk exhibited low SCC [1 and 25 in restricted cows; 12, 29], as was observed in this trial. The increase in SCC during the last third of lactation was

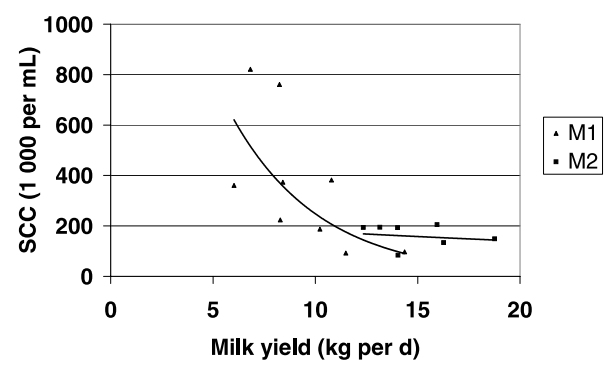

Figure 4. Relationship between milk yield in late lactation (mean of weeks 31 to 41) and somatic cell count during the same period in the groups of cows milked once-a-day (M1) or twice-a-day (M2).

unexpected. The higher proportion of pregnant cows in the M1 group ( 8 of 9) than in the M2 group (4 of 7) as well as the lower milk yield in the M1 group at the end of lactation could partly account for these different SCC results (Fig. 4).

The lack of effect of ODM on plasmin activity and the increase in plasminogenderived activity noted in this trial had already been observed $[24,29,32,40]$. The lack of effect of ODM on lipoprotein lipase (LPL) activity or even its slightly reducing effect, was consistent with the decrease in LPL activity noted in two further trials where the reduction of milking frequency was studied at earlier stages of lactation [32, Chilliard et al., unpublished results]. In addition, this result was consistent with the mid-lactation reduction in free fatty acid concentration in the milk of cows milked on a once daily basis [33]. However, since LPL measurements in this trial were performed at earlier lactation stages (weeks 10 to 28) than in other trials (weeks 30 to 40) where sharp increases in SCC and protein content and lower lactose content were noted, it would be worth verifying the lipolytic system responses to milking frequency at late lactation/pregnancy stages, the latter being known as one of the main factors influencing milk lipolysis levels at the end of lactation [9]. 


\subsection{Nutritional state}

In this trial, as in previous studies [31, 32], ODM did not affect food intake in the early weeks of lactation, or in the first weeks of its application. In another husbandry situation (omission of the dry period in late pregnancy) that also led to a large reduction of milk yield $\left(-7.6 \mathrm{~kg} \cdot \mathrm{day}^{-1}\right.$ for the first 12 weeks of lactation), we did not either observe any difference in the feed intake of previously dried or not-dried cows, for the first 3 months of lactation [30]. Conversely, injections of recombinant bovine somatotropin were shown to augment milk yield within a few days, but food intake only increased after a lag-time of about 6 weeks [10]. In those situations where the yield of milk is modified by management practices (milking frequency, omission of the dry period, administration of somatotropin...), cows seem to progressively adapt their intake to their modified milk yield, after a lag-time of several weeks. As a consequence, our results did not contradict Holmes et al.'s data [18] that reported, in late lactation, a lower grass intake by cows milked once daily than by control cows. Delayed adaptation of intake levels to lower production requirements accounts for the lesser degradation of body condition and reduction of liveweight at the beginning of lactation and the maintenance of, or increase in, that difference throughout the remainder of lactation. Further studies $[11,12,18,31]$ recorded reduced losses and/or slight increases in liveweight and body condition score, in early lactation. These results reflect the better nutritional condition of the cows, also manifested by higher glycemia $[1,18]$. This better nutritional condition was consistent [5] with the higher number of pregnant cows in the M1 group.

\section{CONCLUSION}

ODM of high producing dairy cows does not appear to raise any specific husbandry problem or definitive modifications of milk chemical composition. However, certain authors have expressed their fears that milk issued from ODM may be less suitable for processing. This issue, as well as the impact of ODM in primiparous cows and over several consecutive lactations, would be worth exploring.

\section{AKNOWLEDGEMENTS}

The authors express their very special thanks to M. Barbet and the personnel of the Orcival INRA experimental farm for their excellent experimental work throughout the trial and $\mathrm{Ph}$. Rousseau-Cunningham for English translation and proofreading.

\section{REFERENCES}

[1] Auldist M.J., Prosser C.G., Differential effects of short-term once-a-day milking on milk yield, milk composition and concentration of selected blood metabolites in cows with high or low pasture intake, Proc. N.Z. Soc. Anim. Prod. 58 (1998) 41-43.

[2] Bazin S., Grille de notation de l'état d'engraissement des vaches Pie Noires, Ed ITEB, 149 rue de Bercy, 75595 Paris Cedex $12,1984$.

[3] Bony J., Pomiès D., Le robot de traite ; aspects techniques et économiques, Collection Techniques et Pratiques, Éditions Institut National de la Recherche Agronomique, 147 rue de l'Université, 75338 Paris Cedex 07, 2002.

[4] Bugaud C., Buchin S., Coulon J.B., Hauwuy A., Dupont D., Influence of the nature of alpine pastures on plasmin activity, fatty acid and volatile compound composition of milk, Lait 81 (2001) 401-414.

[5] Butler W., Nutritional interactions with reproductive performance in dairy cattle, Anim. Reprod. Sci. 60-61 (2000) 449-457.

[6] Carruthers V.R., Davis S.R., Bryant A.M., Morris C.A., Selection of cows for once a day milking, Proc. Ruakura Farmer's Conf., 1989, pp. 12-14.

[7] Carruthers V.R., Davis S.R., Bryant A.M., Henderson H.V., Morris C.A., Copeman P.J.A., Response of Jersey and Friesian cows to once a day milking and prediction of response based on udder characteristics and milk composition, J. Dairy Res. 60 (1993) 111. 
[8] Carruthers V.R., Davis S.R., Copeman P.J.A, Effects of oxytocin, machine stripping and milking rate on production loss of cows milked once a day, J. Dairy Res. 60 (1993) 13 18.

[9] Chazal M.P., Chilliard Y., Effect of stage of lactation, stage of pregnancy, milk yield and herd management on seasonal variation in spontaneous lipolysis in bovine milk, J. Dairy Res. 53 (1986) 529-538.

[10] Chilliard Y., Review. Long-term effects of recombinant bovine somatotropin (rBST) on dairy cow performances, Ann. Zootech. 37 (1988) 159-180.

[11] Claesson O., Hansson A., Gustafsson N., Brannang E., Studies on monozygous cattle twins. XVII. Once a day milking compared with twice a day milking, Acta Agric. Scand. 9 (1959) 38-58.

[12] Cooper C., Once-a-day milking: possible and profitable? South Island Dairy Event Proceedings, 2000, pp. 152-163.

[13] Coulon J.B., Rémond B., Variations in milk output and milk protein content in response to the level of energy supply to the dairy cow: a review, Livest. Prod. Sci. 29 (1991) 31-37.

[14] Coulon J.B., Hurtaud C., Rémond B., Vérité R., Factors contributing to variation in the proportion of casein in cow's true protein: a review of recent INRA experiments, J. Dairy Res. 65 (1998) 375-387.

[15] Davis S.R., Farr V.C., Copeman P.J.A., Carruthers V.R., Knight C.H., Stelwagen K., Partitioning of milk accumulation between cisternal and alveolar compartments of the bovine udder: relationship to production loss during once daily milking, J. Dairy Res. 65 (1998) 1-8.

[16] Davis S.R., Farr V.C., Stelwagen K., Regulation of yield loss and milk composition during once-a-day milking: a review, Livest. Prod. Sci. 59 (1999) 77-94

[17] Faulconnier Y., Thévenet M., Fléchet J., Chilliard Y., Lipoprotein lipase and metabolic activities in incubated bovine adipose tissue explants: effects of insulin, dexamethasone, and fetal bovine serum, J. Anim. Sci. 72 (1994) 184-191.

[18] Holmes C.W., Wilson G.F., MacKenzie D.D.S., Purchas J., The effect of milking once daily throughout lactation on the performance of dairy cows grazing on pasture, Proc. N.Z. Soc. Anim. Prod. 52 (1992) 13-16.

[19] INRA (Institut National de la Recherche Agronomique), Ruminant Nutrition, Recommended allowances and feed tables, in: Jarrige
R. (Ed.), INRA Paris and John Libbey Eurotext London, 1989.

[20] Inration. Logiciel de rationnement des ruminants, in: Agabriel J., Champciaux J., Espinasse C. (Eds.), Inration 2.6. CNERTA, $26 \mathrm{Bd} \mathrm{du}$ docteur Petitjean, 21000 Dijon, France, 1989

[21] Kamote H.I., Holmes C.W., MacKenzie D.D.S., Holdaway R.J., Wickham B.W., Effect of once daily milking in later lactation on cows with either low or high initial somatic cell counts, Proc. N.Z. Soc. Anim. Prod. 54 (1994) 285-287.

[22] Kelly A.L., Reid S., Joyce P., Meaney W.J., Foley J., Effect of decreased milking frequency of cows in late lactation on milk somatic cell count, polymorphonuclear leucocyte numbers, composition and proteolytic activity, J. Dairy Res. 65 (1998) 365-373.

[23] Knight C.H., Dewhurst R.J., Once daily milking of dairy cows: relationship between yield loss and cisternal milk storage, J. Dairy Res. 61 (1994) 441-449.

[24] Knutson R.J., MacKenzie D.D.S., Davis S.R., McCutcheon S.N., The effect of once daily milking on concentrations and yields of plasminogen, plasmin and other whey proteins, Proc. N.Z. Soc. Anim. Prod. 53 (1993) 155158.

[25] Lacy-Hulbert S.J., Woolford M.W., Bryant A.M., Influence of once daily milking and restricted feeding on milk characteristics in late lactation, Proc. N.Z. Soc. Anim. Prod. 55 (1995) 85-87.

[26] Lacy-Hulbert S.J., Woolford M.W., Nicholas G.D., Prosser C.G., Stelwagen K., Effect of milking frequency and pasture intake on milk yield and composition of late lactation cows, J. Dairy Sci. 82 (1999) 1232-1239.

[27] Levieux D., Dosage des IgG du lait de vache par immodiffusion radiale semi-automatisée, pour la détection du colostrum, des laits de mammites ou de fin de gestation - I - Mise au point du dosage, Lait 71 (1991) 327-338.

[28] Lynch G.A., Hunt M.E., Mackenzie D.D.S., The effects of once daily milking as a management practice in late lactation, Proc. N.Z. Soc. Anim. Prod. 51 (1991) 191-195.

[29] O’Brien B., Ryan G., Meaney W.J., McDonagh D., Kelly A., Effect of frequency of milking on yield, composition and processing quality of milk, J. Dairy Res. 69 (2002) 367-374.

[30] Rémond B., Rouel J., Pinson N., Jabet S., An attempt to omit the dry period over three consecutive lactations in dairy cows, Ann. Zootech. 46 (1997) 399-408. 
[31] Rémond B., Coulon J.B., Nicloux M., Levieux D., Effect of once-a-day milking in early lactation on milk production and nutritional status of dairy cows, Ann. Zootech. 48 (1999) 341-352.

[32] Rémond B., Aubailly S., Chilliard Y., Dupont D., Pomiès D., Petit M., Combined effects of once-a-day milking and feeding level in the first three weeks of lactation on milk production and enzyme activities, and nutritional status in Holstein cows, Anim. Res. 51 (2002) 101-117.

[33] Rémond B., Pradel P., Pomiès D., Petit M., Effet de la traite une fois par jour, pendant sept semaines, de vaches laitières en milieu de lactation, Renc. Rech. Ruminants 9 (2002) 203.

[34] Rowland S.J., The determination of the nitrogen distribution in milk, J. Dairy Res. 9 (1938) 42-46.

[35] Statistical Analysis System Institute, SAS User's Guide: Statistics, SAS Institute, Inc., Cary, North Carolina, USA, 1992.

[36] Stelwagen K., Effect of milking frequency on mammary functionning and shape of the lactation curve, J. Dairy Sci. 84 (Suppl. E.) (2001) E204-E211.

[37] Stelwagen K., Lacy-Hulbert S.J., Effect of milking frequency on milk somatic cell count characteristics and mammary secretory cell damage in cows, Am. J. Vet. Res. 57 (1996) 902-905.
[38] Stelwagen K., Knight C.H., Effet of unilateral once or twice daily milking of cows on milk yield and udder characteristics in early and late lactation, J. Dairy Res. 64 (1997) 487494.

[39] Stelwagen K., Davis S.R., Farr V.C., Eichler C.J., Politis I., Effect of once daily milking and concurrent somatotropin on mammary tight junction permeability and yield of cows, J. Dairy Sci. 77 (1994) 2994-3002.

[40] Stelwagen K., Politis I., White J.H., Zavizion B., Prosser C.G., Davis S.R., Farr V.C., Effect of milking frequency and somatotropin on the activity of plasminogen activator, plasminogen, and plasmin in bovine milk, J. Dairy Sci. 77 (1994) 3577-3583.

[41] Stelwagen K., Farr V.C., McFadden H.A., Prosser C.G., Davis S.R., Time course of milk accumulation-induced opening of mammary tight junctions, and blood clearance of milk components, Am. J. Physiol. 273 (1997) 379_ 386.

[42] Vetharaniam I., Davis S.R., Soboleva T.K., Shorten P.R., Wake G.C., Modeling the interaction of milking frequency and nutrition on mammary gland growth and lactation, J. Dairy Sci. 86 (2003) 1987-1996.

[43] Woolford M.W., Copeman P.J.A., Napper A.R., Phillips D.S.M., Williamson J.H., Ulfee E.J., Milking intervals: are changes worthwhile? Proc. Ruakura Farmer's Conf., 1985, pp. $120-128$. 